\title{
Register in Persaudaraan Setia Hati: Sociolinguistics study
}

Juwita Dwi Kartikasari ${ }^{1}$, S. Sumani ${ }^{1}$, Rosita Ambarwati ${ }^{1}$

${ }^{1}$ Department of English Teaching, Universitas PGRI Madiun, Indonesia

\begin{tabular}{l}
\hline \hline Article Info \\
\hline Article history: \\
Received May 14, 2018 \\
Revised October 10, 2018 \\
Accepted November 11, 2018 \\
\hline
\end{tabular}

\section{Keywords:}

Language Variety

Register

Facebook group

Persaudaraan Setia Hati

Social Meaning.

\begin{abstract}
Madiun is a regency in East Java which is known as Kampung Pesilat. Persaudaraan Setia Hati is an organization was made by Ki Ngabehi Surodiwirdjo, Persaudaraan Setia Hati is a way of living and a life's path. That is not a fighting sport but a fighting art. A fighting sport is a struggle with another and a fighting art is a struggle with oneself. Persaudaraan Setia Hati is a combination of the two brotherhood and founded on five basic principles, brotherhood/ friendship, sport, self-defense, art and culture, and spiritual development which represent in the symbols of the Persaudaraan Setia Hati emblem. Thus, the researcher uses socio-cultural theory which appear register forms. The objectives of this study are to describe the register, context, social meaning of register used by Persaudaraan Setia Hati. The approach of this study is qualitative research and the type of the research is case study because the researcher can identify the register forms that used Persaudaraan Setia Hati and social meaning in society. The researcher shows the data on screenshot of the original conversation each member which is taken from Facebook group Persaudaraan Setia Hati. Analysis technique flow model of this study are data condensation, displaying data, and concluding. The result of this study are (1) there are some register words found in the data that categories the context as follows: the participants are about the relationship between each member, the setting describes from the place where the conversation happened, the topic are about daily life experiences, the function as the motivation and self reminder for each member (2) social meaning are about brotherhood/friendship, sport, selfdefense, art and culture, spiritual development.
\end{abstract}

Copyright $@ 2018$ Department of English Teaching. All rights reserved.

\section{Corresponding Author:}

Juwita Dwi Kartikasari,

Department of English Teaching,

Universitas PGRI Madiun,

Jalan Setiabudi No.85 Madiun, Eas Java, Indonesia.

Email: juwitadwikartikasari22@gmail.com

\section{INTRODUCTION}

Language is a system of communication which people used to convey and express their ideas, desire, and feelings. All human beings normally speak at least one language or more. As quoted by Wardhaugh (2006:1) "We may attempt an equally comprehensive definition of language: language is what the members of particular society speech. However, as we will see, speech in almost any society can take many very different forms, and just what forms we should choose to discuss when we attempt to describe the language of a society may prove to be a contentious matter." From the quotation, it can be concluded that language and society are two things which are inseparable to support each other. Therefore, language as a tool which help people to convey what they want share in society.

In society people use more than one language to communicate with others. Sometimes people make a group which speak the same language or the same dialect or the same variety in order to be unity. The kind of group that sociolinguists have generally attempted to study is called speech community. Wardhaugh 
(2006:119) stated, "It remains so even if we decide that a speech community is not more than some kind of social group whose speech characteristics are of interest and can be described in a coherent manner." Based on the quotation, a speech community is not only a group which used a language that unique, but also a group which have rules and obligation for each member to communicate with others.

People created a group together for one or more reasons: social status, economic values, political situation, culture, social prestige etc. A group must have at least two members, and a group might be create new words which unique and show up with their styles. It is caused by the certain condition of the the influence of the society which have so many variety. Language varies according to its use, moreover, it also varies in its style. Hudson (in Wardhaugh, 2006:25) "Defines a variety of language as a set of linguistic items with similar social distribution because what makes one variety of language different from another is the linguistic items." Those definitions clearly explain language which is used by people to communicate with other in society is varied and what make its different in linguistic items.

Sociolinguistic is a study of language which is associated with social conditions and takes language as an object of the study. According to Yule (2010:254) "The term sociolinguistics is used generally for the study of the relationship between language and society." It can be concluded that, sociolinguistics studies the social uses of languge and the social evaluation of language variations. Sociolinguistics refers to correlation between language and society, between particular linguistics and social phenomena which are explores and explains why some people speak differently in different social contexts, the functions and the varieties of language, the contacts between different languages, attitudes of people towards language use and users, changes of language and so on.

There are so many language varieties in sociolinguistic, register is a kind of language varieties. A register is a variety of language most likely to be used in a specific situation and with particular roles and status involved. Register is a kind of language variety in sociolinguistics which is used in certain group or community. Register represents a language variety that is based on its function. According to Yule (2010 : 259) "A register is a conventional way of using language that is appropriate in a specific context, which may be identified as situational (e.g. in church), occupational (e.g. among lawyers) or topical (e.g. talking about language)." It can be concluded that, register is a language uses of words which is associated with some groups or community that have same topic or object and it was shared by each members of group itself. Here, only the member of groups who understand the deeply meaning each words. Usually, the patterns of register follow the existing of community either by addition or reduction, it is so dynamic and always follows the development of the society.

Pencak Silat or martial art is the traditional art of Indonesia and it is known as the art of self-defense based on a philosophy which is associated with code and ethnics. Pencak silat is used mainly in Indonesia, some 16 million people practice and join 800 styles of Pencak Silat especially Persaudaraan Setia Hati. PSH is a way of living and a life's path. That is not a fighting sport but a fighting art. A fighting sport is a struggle with another and a fighting art is a struggle with oneself.

The history of Persaudaraan Setia Hati is abbreviated PSH began in 1903 that the forming of Sedulur Tunggal Kecer (STK) in Tambak village Surabaya by the late Ki Ngabehi Soerodwirjo. He founded the brotherhood of the family is Sedulur Tunggal Kecer (STK), the name of the martial art is "Djojo Gendilo". In 1917 he changed STK become PSH and the name of the martial art is “Djojo Gendilo Tjipto Mulyo." PSH 
doing the demonstration at Alon-alon Madiun and popular in the society because it has the movement unique art-filled and powered. Then, well known as Persaudaraan Setia Hati Tunas Muda Winongo (PSHTMW). In 1922 Ki Hadjar Hardjo Oetomo is militants student of Mbah Suro founded the new brotherhood which is organized named "Pemuda Sport Club", he changed PSC into "Setia Hati Muda (SHM)". Because of his perseverance against the Dutch, he replaced SHM into Persaudaraan Setia Hati Terate (PSHT) with the permission of Mbah Suro. PSH is a combination of the two brotherhood and founded on five basic principles, brotherhood/ friendship, sport, self-defense, art and culture, and spiritual development which represent in the symbols of the Persaudaraan Setia Hati emblem. Here are the family tree of PSH:

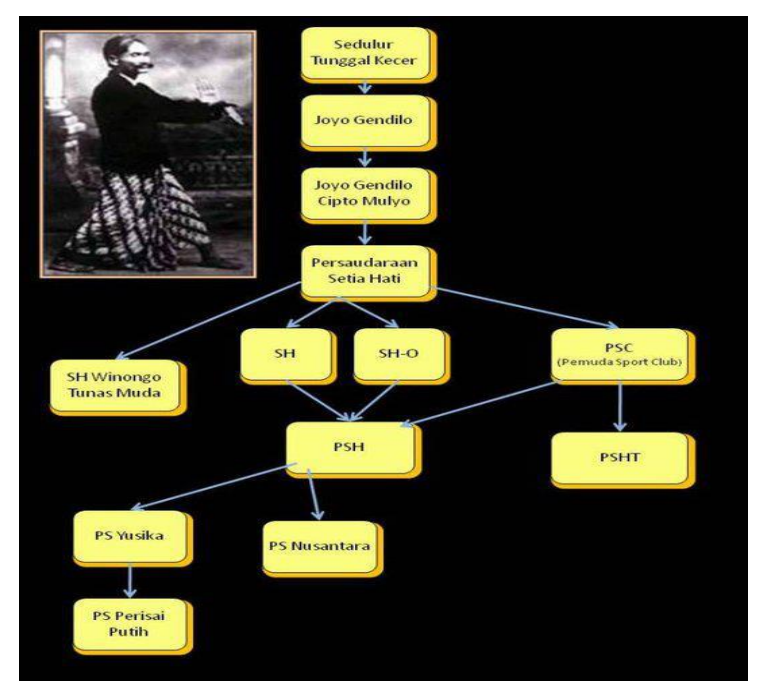

Figure 1. Family tree of PSH

PSH is a kind of community. Here, they used specific words to communicate with each member. Language which they used is to express their mind, feeling, creation, innovation, and so on. There are several reasons why they have done register in society, such as quoting someone, marking and emphasizing group identity or solidarity, raising status, and showing language expertise. They use register in society as an identity of their group that might be different with other groups. Therefore this phenomenon of language which happens in society giving social impact and ambiguity each word which they created, because only the member of group who knows the deeply meaning specific word.

This phenomenon can be observed mostly in society absolutely by Persaudaraan Setia Hati (PSH) group in Facebook. The aim of this research is to describe register words used in society by Persaudaraan Setia Hati (PSH). Many researchers have conducted the study of registers. The following one of them is Alis Rahmawati (2014) who consulted “A Sociolinguistics Analysis of Register Used in Soccer Page of Social Media Facebook." which analyzes and give some information about register words which used by group. The researcher found the linguistic form of words, phrases and the meaning based on the context situation. It happens when the maintenance posts the news updates certainty about soccer, such as score updates, news of last match, and news the player or specific club.

\section{METHOD}

The approach of this research is qualitative research to design the framework of the research technique in detail and systematic. According to Heigham \& Crocker (2009 :4) "Qualitative research in applied 
linguisticsis a broad and exciting interdisciplinary field of study. It focuses on language in use, connecting our knowledge about languages with an understanding of how they are used in the real world."It clearly explains that qualitative research is a study which focussed on language in use by the people and how they are used language in real life that appears and needs to be explaining.

The type of the research is case study, according to Heigham \& Crocker (2009: 68) "A simple definition of case study is elusive. Perhaps the main reason for this is that case study is often looked at as a research method, rather than a research focus. It is expected that the study will provide in-depth description and analysis of a 'bounded system' - one individual, institution, or educational context and rich data." It can be conclude that this research belongs to descriptive qualitative research which is defined individual or entity in real life. The data taken from screenshot of original conversation without change the conversation and the researcher can explore the data in facebook group of Persaudaraan Setia Hati, especially to identify register forms in depth which is used by Persaudaraan Setia Hati and to describe social meaning in society.

The source of the data in this research is document. In this research, the researcher uses document because the data comes from original screenshot the conversation each member which is contain the register words and originally taken from official website facebook group of Persaudaraan Setia Hati. The researcher collects the data by documentation uses content analysis technique and observation technique because the researcher should explore the deeply meaning of register words based on the conversation and collect the data from official website facebook group of Persaudaraan Setia Hati. The data are sentences containing the register words and phrases taken from screenshoot which is posted in Persaudaraan Setia Hati group at social media Facebook.

The data analysis technique in this research is document analysis. The research conducts an analysis of the screenshoot which posted by the member of Persaudaraan Setia Hati using the theory Miles, Huberman \& Saldaña (2014: 31-33) who define analysis as consisting of three concurrent flows of activity those are, data condensation refers to the process of searching and selecting trusted facebook group of Persaudaraan Setia Hati then, join to be the member and observe the group, so the researcher can read all of the post, know anything what they shared in group and tries to find some words that belong to register words. Then, data display is the second major flow of analysis activity and the data must be displayed with the infomation have been compressed. Here, the researcher display the data uses table because it simple, extract the data in detail, and it will be easily to draw conclusion at the end. The last is drawing and verifying conclusions is the third stream of analysis activity. The researcher summarize from the start of data collection until the end, the qualitative analyst interprets what things mean by noting patterns, explanations, causal flows, and propositions. The researcher must write down, elaborate, summarize the important points and review as brief.

\section{RESULTS AND DISCUSSION}

The researcher found fifty data, but in this section the researcher represents five data which have got from screenshot and it is collected while the researcher was following the group Facebook of Persaudaraan Setia Hati. The data are the result of observation and consists of register form that posted by the member of Persaudaraan Setia Hati at the group Facebook. In this chapter represents the socio-cultural context which has four components such as participants, setting, topic, and function in Persaudaraan Setia Hati. 
Figures of Persaudaraan Setia Hati :

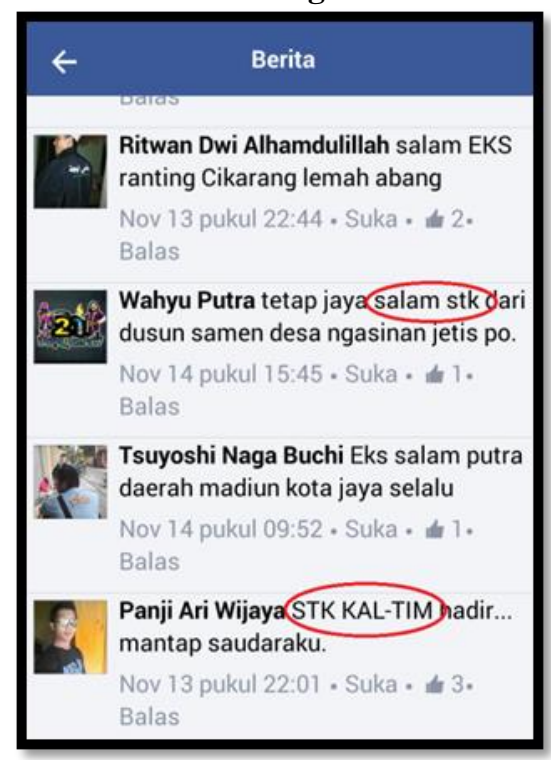

Figure 2.

\begin{tabular}{|c|c|}
\hline$\leftarrow$ & Berita \\
\hline & Okt 14 pukul 16:01 - Suka. Balas \\
\hline & $\begin{array}{l}\text { Baba Abdul sing tawuran kui gur } \\
\text { provokator lur, asline T karo W ayem } \\
\text { tentrem } \\
\text { Okt } 18 \text { pukul } 23: 18 \text { - Suka. Balas }\end{array}$ \\
\hline & $\begin{array}{l}\text { Didikwiboeo Wibowo Swiep contoh } \\
\text { telandan kui.ojo sok ngaku pendekar } \\
\text { nk gk iso dadi contoh sing apik. } \\
\text { Okt } 20 \text { pukul } 12: 39 \text {. Suka. Balas }\end{array}$ \\
\hline & $\begin{array}{l}\text { Alex Trump Saya pikir2 Klau SH } \\
\text { winongo madhioen mantap N Jaya } \\
\text { sllu tapi kalau Ashwin } 4 \text { shter } \\
\text { Yg menang Ashwin } 00000 \% \text { sbb } \\
\text { teknik2 Ny mantap pas sasaran } \\
\text { Okt } 20 \text { pukul } 01: 06 \text {. Suka } \text {. } 1 \text {. } \\
\text { Balas }\end{array}$ \\
\hline & 1 Balasan \\
\hline
\end{tabular}

Figure 4.

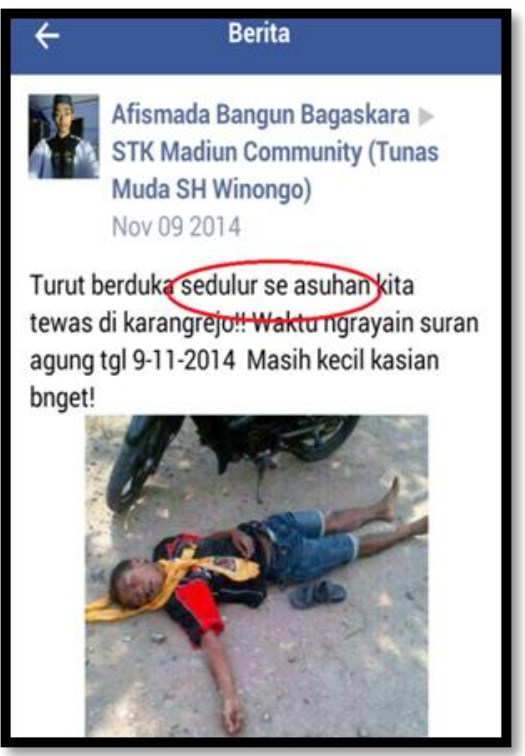

Figure 3.

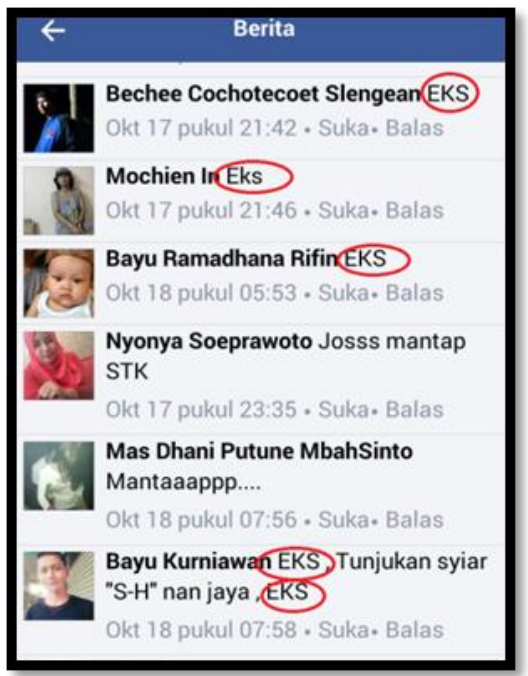

Figure 5.

Berita
Oks 26 pukul 12:26 a
Sehubungan dengan adanya kegiatan kecer
di bekasi tgl 29/10/2016 serta Suran Agung
wilayah jadebotabek di bekasi pd hr
minggu tgl 30/10/2016,maka dengan ini
diberitahukan bahwa kecerdi padepokan
pusat tgl 29 Okt 2016 ditiadakan,mohon
pemberitahuan ini diteruskan kpd saudara"
yg lain.
Demikian pemberitahuan kami sampaikan
Wassalamualaikum wr wb
O Dibagikan dengan: Publik
Okt 26 pukul 12:26

Figure 6. 
Table 1. Data of Register Forms among Persaudaraan Setia Hati which is appropriated with socio-cultural context.

\begin{tabular}{|c|c|c|c|c|c|}
\hline \multirow[t]{2}{*}{ Figure } & \multirow{2}{*}{ Data } & \multicolumn{4}{|c|}{ Socio-cultural context } \\
\hline & & $\mathrm{P}$ & $\mathrm{S}$ & $\mathrm{T}$ & $\mathrm{F}$ \\
\hline 2 & $\begin{array}{l}\text {-tetap jaya salam STK dari } \\
\text { dusun samen... } \\
\text { (Keep glorious STK greeting } \\
\text { comes from dusun samen...) } \\
\text {-STK KAL-TIM hadir... } \\
\text { (STK KAL-TIM presence...) }\end{array}$ & $\begin{array}{l}\text { Member } \\
\text { of group } \\
\text { FB }\end{array}$ & $\begin{array}{l}\text { Social } \\
\text { Media } \\
\text { Face } \\
\text { book }\end{array}$ & Greets each other & $\begin{array}{l}\text { Expression of } \\
\text { greeting and start } \\
\text { a conversation to } \\
\text { discuss } \\
\text { something. }\end{array}$ \\
\hline 3 & $\begin{array}{l}\text { Turut berduka } \\
\text { sedulurseasuhan kita tewas } \\
\text { di Karangrejo.. } \\
\text { ( I'm so sorry for the death } \\
\text { of our brotherhood who had } \\
\text { died in Karangrejo) }\end{array}$ & $\begin{array}{l}\text { Admin of } \\
\text { group FB }\end{array}$ & $\begin{array}{l}\text { Social } \\
\text { Media } \\
\text { Face } \\
\text { book }\end{array}$ & $\begin{array}{l}\text { Inform that there } \\
\text { was a } \\
\text { member had died } \\
\text { in Karangrejo. }\end{array}$ & $\begin{array}{l}\text { Stating specific } \\
\text { information for } \\
\text { the member of } \\
\text { group. }\end{array}$ \\
\hline 4 & $\begin{array}{l}\text {...tapi kalau Ashwin vs } \\
\text { Ashter.... } \\
\text { (..but if } \underline{\text { Ashwin vs Ashter....) }}\end{array}$ & $\begin{array}{l}\text { Member } \\
\text { of group } \\
\text { FB }\end{array}$ & $\begin{array}{l}\text { Social } \\
\text { Media } \\
\text { Face } \\
\text { book }\end{array}$ & $\begin{array}{l}\text { Compare their } \\
\text { group with other }\end{array}$ & $\begin{array}{l}\text { An abbreviation } \\
\text { which is } \\
\text { meaningful. }\end{array}$ \\
\hline 5 & $\frac{E K S}{H ” .}$, Tunjukan syiar " $S$ - & $\begin{array}{l}\text { Member } \\
\text { of group } \\
\text { FB }\end{array}$ & $\begin{array}{l}\text { Social } \\
\text { Media } \\
\text { Face } \\
\text { book }\end{array}$ & Greets each other & $\begin{array}{l}\text { Expression of } \\
\text { greeting. }\end{array}$ \\
\hline
\end{tabular}

\begin{tabular}{|c|c|c|c|c|c|}
\hline & $\begin{array}{l}\text { ( } \underline{E S S}, \text { show off our } \\
\text { greatness " } S-H \text { "..) }\end{array}$ & & & & \\
\hline 6 & $\begin{array}{l}\text { Kegiatan kecer di Bekasi } \\
\text { tanggal..... } \\
\text { (An activity about kecer that } \\
\text { would be held in Bekasi } \\
\text { at....) }\end{array}$ & $\begin{array}{l}\text { Admin of } \\
\text { group FB }\end{array}$ & $\begin{array}{l}\text { Social } \\
\text { Media } \\
\text { Face } \\
\text { book }\end{array}$ & $\begin{array}{l}\text { Inform about } \\
\text { kecer would be } \\
\text { cancelled. }\end{array}$ & $\begin{array}{l}\text { Stating specific } \\
\text { information for } \\
\text { the member of } \\
\text { group. }\end{array}$ \\
\hline
\end{tabular}

Based on the table above, the researcher found some register words used by the member of Persaudaraan Setia Hati.The researcher screenshot the real conversation between each member of group in Facebook. In the first column shows data based on the conversation. Then, the second data present about transcript of conversation. Third column presents about the participants $(\mathrm{P})$. Then, fourth column represents about where they are talked (S). Then, the topic what they are talked about (T), and then the function of conversation (F). The last column represents the domains of language use. So, the researcher can ident ify and analyze who are the participants $(\mathrm{P})$, the setting where they are talked (S), the topic what they are talked about (T), and what is the function (A) which represents in table.

In this part, the researcher discusses about the result of the research. Based on the data presentation, the researcher analyze the "Register In Persaudaraan Setia Hati: Sociolinguistics Study". In this chapter is intended to discuss the finding based on the formulation of problem, as follow:

Figure 2 shows one of the members was greeting one another used specific word such as "Salam STK”. Here, the participants are the members of group who often doing the interaction in the Facebook group Persaudaraan Setia Hati Tunas Muda Winongo, and a social distance each member is intimate because this group are about brotherhood and unity which have high solidarity. So, while the entire members speaks, the 
formality scale of language choice that they are used is informal way which is automatically the status scale is subordinate that reflected lower social group status in the society. Based on the data obtained, the setting of the conversation that happens between the entire members of group occur on the Facebook group Persaudaraan Setia Hati Tunas Muda Winongo .Then, the topic which is discussed by the entire members is greets each other and start a conversation. Figure 3.1 "Salam STK" it categorized as register word because that is a specific word which is meaningful for each member of Persaudaraan Setia Hati Tunas Muda Winongo. That word is one of the ways to greet each member especially Persaudaraan Setia Hati Tunas Muda Winongo. The function of that conversation is to strengthen the relationship and brotherhood each member. They always greet each other as well as express admiration and respect others. The type of function scale is referential which was expressing about high information content, it has told about one of the members tried to greet another to start a conversation in group. Then, another member replied the greetings and they have begun to discuss something.

Figure 3Here, the participants are the members of group who often doing the interaction in the Facebook group Persaudaraan Setia Hati Tunas Muda Winongo, and a social distance each member is intimate because this group are about brotherhood and unity which have high solidarity.The status scale in Figure 3.2 represents that one of the member group inform bad news and called Sedulur which is reflected subordinate. Here, the informant said "Sedulur Seasuhan", it categorized register word because that word have deep meaning about brotherhood and only the member who used that word. This word only used by certain people. This scale point shows low status because the language used the member of group who inform in Facebook group is informal way that indicated low formality. Based on the data obtained, the setting of the conversation that happens between the entire members of group occur on the Facebook group Persaudaraan Setia Hati Tunas Muda Winongo. Then, the topic which is discussed by the entire members informs bad news that there wasa Pendekar Persaudaraan Setia Hati Tunas Muda Winongo who had died in Karangrejo while they were celebrating Suran Agung. Another group stopped his group while they were going home after they were celebrating Suran Agung and beating till he died. The function of informs anything in Facebook group Persaudaraan Setia Hati Tunas Muda Winongo in order to give news information about the development of organization and the type of function scale is referential which was expressing about high information content, it has told about one of the members inform bad news to the entire member about that there was a Pendekar Persaudaraan Setia Hati Tunas Muda Winongo who had died in Karangrejo.

Figure 4. Here, the participants are the members of group who often doing the interaction in the Facebook group Persaudaraan Setia Hati Tunas Muda Winongo, and a social distance each member is intimate because this group are about brotherhood and unity which have high solidarity. The status scale in Figure 4. is subordinate which is reflected low status because in Figure 3.3 shows one of the member called Lur to other members. That is indicated informal way of interaction. Based on the data obtained, the setting of the conversation that happens between the entire members of group occur on the Facebook group Persaudaraan Setia Hati Tunas Muda Winongo. Then, the topic which is discussed by the entire members is compare their group with other, in Figure 4. represent that one of the member group mentioned about “ASHWIN and ASHTER”that words are abbreviation which is meaningful. The function why the members applied that word as a comparison and to show their identity that they are the member of Persaudaran Setia 
Hati Tunas Muda Winongo who invicible. The type of function scale is referential which was expressing about high information content which is clearly explained about two organizations that never get along even though the founder is same Ki Ngabehi Surodiwirdjo.

Figure 5. Here, the participants are the members of group who often doing the interaction in the Facebook group Persaudaraan Setia Hati Tunas Muda Winongo, and a social distance each member is intimate because this group are about brotherhood and unity which have high solidarity. So, while the entire members speaks, the formality scale of language choice that they are used is informal way which is automatically the status scale is subordinate that reflected lower social group status in the society. Based on the data obtained, the setting of the conversation that happens between the entire members of group occur on the Facebook group Persaudaraan Setia Hati Tunas Muda Winongo. Then, the topic which is discussed by the entire members is greets each other and start a conversation. Figure 5. shows one of the members was greeting one another used specific word such as "EKS". It categorized as register word because that is a specific word which is meaningful for each member of Persaudaraan Setia Hati Tunas Muda Winongo. That word is one of the ways to greet each member especially Persaudaraan Setia Hati Tunas Muda Winongo. The function of that conversation, greetings is to strengthen the relationship and brotherhood each member. They always greet each other as well as express admiration and respect others. Sometimes this greeting is also used when they meet each other. The type of function scale is referential which was expressing about high information content which is clearly explained about one of the members tried to greet another to start a conversation in group. Then, another member replied the greetings and they have begun to discuss something.

Figure 6. Here, the participants are the admin of group who given the information to the entire member of Facebook group Persaudaraan Setia Hati Tunas Muda Winongo, and a social distance each member is intimate because this group are about brotherhood and unity which have high solidarity. The status scale in Figure 6. is superior, because the language choice of Saudara in Figure 6. reflected high status in that conversation. It categorized register word because that word have deep meaning about brotherhood and only the member who used that word. This word only used by certain people. The admin of group uses formal way while informed the information to respect the entire members and shows high formality. Based on the data obtained, the setting of the conversation that happens between the entire members of group occur on the Facebook group Persaudaraan Setia Hati Tunas Muda Winongo. Then, the topic which is discussed by the entire members is the admin of group had been informing for the entire member of group Persaudaraan Setia Hati Tunas Muda Winongo about "Kecer" that would be held on October 29, 2016 in Padepokan Pusat Bekasi and Suran Agung that would be held on Sunday October 30, 2016 but it would be cancelled. Then, the admin of group want this information shared to another member. The function of informs anything in Facebook group Persaudaraan Setia Hati Tunas Muda Winongo in order to give news information about the development of organization and the type of function scale is referential which was expressing about high information content, it has told about "Kecer"which means an idiom that expressed an activity the acceptance of new members by Persaudaraan Setia Hati Tunas Muda Winongo.

The researcher gets the data through observation in Facebook group, here the data presentation shows the social meaning originality each word which is post at Facebook group Persaudaraan Setia Hati, the definition are described below: 
2. tetap jaya salam STK dari dusun samen ... and STK KAL-TIM hadir... Morphological process of word STK is Sedulur Tunggal Kecer STK is an abbreviation of phonemes Sedulur Tunggal Kecer The reduction phonemes are $/ S / / T / / K /$

The additional phonemes are $/ e /, / d /, / u /, / /, / u /, / r / / u /, / n /, / g /, / g /, / a /, / l /$

lel,/cl,/el,/r/.

Based on the morphological process above it can be concluded that the abbreviation of $S T K$ comes from Sedulur Tunggal Kecer which means an expression of greeting to other member that used specific words or codes and only the member who knows the deeply meaning each word. Here, the social meaning of STK (Sedulur Tunggal Kecer) is about brotherhood which is indicated they are the member of Persaudaraan Setia Hati. The reason why this organization uses this word in order to easier the member recognize each member of Persaudaraan Setia Hati.

3. Turut berdukasedulurseasuhan kita tewas di Karangrejo..

Morphological process of word Sedulur Seasuhan is Sedulur Tunggal Kecer

Sedulur Seasuhan is a change of the phonemes Sedulur Tunggal Kecer

The reduction phonemes are $/ t /, / u /, / n /, / g /, / g /, / a /, / l / / k /, / e /, / c /, / e /, / r /$.

The additional phonemes are $/ s /, / e /, / a /, / s /, / u /, / h /, / a /, / n /$

Based on morphological process above can be concluded that the word Sedulur Seasuhan means an expression of greeting to other member which is used specific words or codes that only the member who knows the deeply meaning each word. Here, the social meaning of Sedulur Seasuhan are about brotherhood, unity, and show solidarity in Facebook group which is indicated they are the member of Persaudaraan Setia Hati. The reason why this organization uses this word in order to easier the member recognize each member of Persaudaraan Setia Hati.

4....tapi kalau Ashwin vs Ashter....

Morphological process of word Ashwin and AshterareAnak setia Hati Winongo and Anak Setia

Hati Terate

Ashwin and Ashter is an abbreviation of phonemes Anak setia Hati Winongo and Anak Setia Hati

Terate

The reduction phonemes are $/ a /, / s /, / h /, / w /, / i /, / n / / a /, / s /, / h /, / t /, / e /, / r /$

IThe additional phonemes are $/ n /, / a /, / k / / e /, / t /, / i /, / a / / a /, / t /, / i / / o /, / n /, / o /, / n /, / g /, / o /$ and $/ n /, / a /, / k /$ /e/,/t/,/i/,/a//a/,/t/,/i//a/,/t/,/el

Based on morphological process above it can be concluded that the word Ashwin and Ashter comes from Anak setia Hati Winongo and Anak Setia Hati Terate which means an abbreviation two organizations of Persaudaraan Setia Hati compare their group with other used an abbreviation.Here, the social meaning of Ashwin and Ashter (Anak setia Hati Winongo and Anak Setia Hati Terate) is about brotherhood which is indicated they are the member of Persaudaraan Setia Hati. The reason why this organization uses this word in order to easier the member recognize each member of Persaudaraan Setia Hatiand as a code that only the member who knows the deeply meaning each word.

5. EKS, Tunjukan syiar " $S$ - $H$ ”..

Morphological process of word EKS isEleng Kuat Slamet

$E K S$ is an abbreviation of phonemes Eleng Kuat Slamet

The reduction phonemes are $/ E /, / K /, / S /$

The additional phonemes are $/ l /, / e /, / n /, / g / / u /, / a /, / t / / l /, / a /, / m /, / e /, / t /$

The morphological process above concluded that the word EKS comes from Eleng Kuat Slamet which means an expression of greeting to other member which is used specific words or codes that only the member who knows the deeply meaning each word. Here, the social meaning of EKS (Eleng Kuat Slamet)is about brotherhood which is indicated they are the member of Persaudaraan Setia Hati. The reason why this organization uses this word in order to easier the member recognize each member of Persaudaraan Setia Hati. 
6. Kegiatan kecer di bekasi tanggal.....

Morphological process of word is Kecer

The phonemes of Keceris $/ k /, / e /, / c /, / e /, / r /$

The morphological process above concluded that the word Kecer means an an approval that obligate the entire members would be cancelled that is a code and only the member who knows the deeply meaning that word. Here, the social meaning of Kecer is about an appointment which is the member should obey appropriate with the rules. The reason why this organization uses this word in order to easier the member recognize each member of Persaudaraan Setia Hati.

\section{CONCLUSION}

Based on data analysis the research find out the form of register words and social meaning that used by Persaudaraan Setia Hati that represents in the previous chapter. In the previous chapter represents the result of the observation in Facebook group Persaudaraan Setia Hati which is showed the originality conversation of each member that posted at Facebook group Persaudaraan Setia Hati. The researcher found some member of group stated specific words that indicated register words. All the conclusion of research can be stated as follows:

1. The form of register words used by Persaudaraan setia Hati

In the research finding, the researcher displays the fifty data that indicated linguistics forms of register founded in Persaudaraan Setia Hati. There are some discussions from the table. The discussion explains about some register words found in the data and each word has different socio-cultural context from four classifications as follows: participant describe the relationship between each member, setting describes from the place where the conversation happened, topic is about daily life experiences, and the last is function is about the motivation and self reminder for each member.

2. Social meaning of register word used by Persaudaraan Setia Hati

Fifty words which are represents have different meaning and different social meaning. The researcher classify information about social meaning which are divided into five elements, such as brotherhood/ solidarity, sport, self-defense, art and culture, and spiritual development. The member of group uses specific language which is conducted by their own language to secretly hide information from strange people.

\section{REFERENCES}

Club, Prajurit Penjaga Tiang Utara. (2009). Sejarah SH Terate dan Sh Tunas Muda Winongo. Retrieved from http://prajuritpenjagatiangutaraclub.blogspot. co.id/2009/03/sejarah-pecahnya-sh-teratedengan.htmlaccessed on Monday, March 16, 2009

Facebook Lite. (2017). Facebook Lite (Version 54.0.0.2.86) \{Mobile application software\} Retrieved from http://www.akucintastk.blogspot.com/ accessed on April, 20th 2017

Facebook Lite. (2017).Facebook Lite (Version 54.0.0.2.86) \{Mobile application software\} Retrieved from http://shwinongo.com/ accessed on April, 20th 2017

Facebook Lite. (2017). Facebook Lite (Version 54.0.0.2.86) \{Mobile application software\} Retrieved from https://mobile.facebook.com/ PSHT (PERSAUDARAAN-SETIA-HATI-TERATE)/ accessed on April, 20th 2017

Facebook Lite. (2017). Facebook Lite (Version 54.0.0.2.86) \{Mobile application software\} Retrieved fromhttps://mobile.facebook.com/ Perkumpulan-PENCAK-SILAT-seNUSANTARA/ accessed on April, 20th 2017 
Heigham, J. \& A. C. R. (2009). Qualitative Research in Applied Linguistics. United Kingdom. Palgrave Macmillan.

Holmes, J. (1992). An Introduction to Sociolinguistics. United States of America. Longman Group UK Limited.

Kothari, C.R. (2004) Research Methodology Method and Techniques (Second Revised Edition). New Delhi: Sage Publication.

Miles, B. M., Hubberman, A. Ml, \& Saldana, J. (2014). Qualitative Data Analysis 3rd edition. United States of America. SAGE Publications.

Rahmawati, A. (2014). A sociolinguistics analysis of registerused in soccer page of social media facebook. Surakarta. Muhammadiyah University of Surakarta. Retrieved from http://eprints.ums.ac.id/29797/9/PUBLICATIONS ARTICLE.pdf

Silat Indonesia. (2015, February 26). Sejarah PSHT, Indonesian Martial Art Pencak Silat, Historty of Persaudaraan Setia Hati Terate. Retrieved from http://www.youtube.com accessed on February 26, 2015

Spolsky, B. (1998). Sociolinguistics. New York. Oxford University Press.

Wardhaugh, R. (2006). An Introduction to Sociolinguistics. Oxford: Blackwell Publishers Ltd.

Yule, G. (2010). The Study of Language. New York: Cambridge University Press. 